\title{
Effectiveness of Fiscal Policies in Stabalizing Global Economy
}

\author{
Dr. Abachi Terhemen Philip \\ Department of Economics, Benue State University, Makurdi, Nigeria
}

\begin{abstract}
The paper examined the effectiveness of fiscal policies in stabilizing the global economy. The annual growth rate and some macroeconomic variables such as inflation rate, unemployment rate and exchange rate for selected advanced and developing economies are used for the analysis. Time series data for these variables were obtained basically from the World Bank and tables, percentages and line graphs are the tools used to analyze the data. The results revealed that the annual growth rate for the advanced economies has been relatively stable, except for the global economic crisis which affected almost all the selected advanced countries. For the developing economies, the growth rate showed gross instability which does not follow any defined pattern. The macroeconomic variables examined showed that fiscal policies are effective in stabilizing advanced economies but not so with the developing economies. High level of corruption, insecurity, rigid and narrow tax structure are identified as the major challenges working against the effectiveness of fiscal policies in developing economies It is expected that when these challenges are addressed, fiscal policies will be more effective in stabilizing economies of developing countries.
\end{abstract}

Key Words: Corruption, Economy, Effectiveness, Fiscal policy, Global

\section{Introduction}

Fiscal policies refer to the policies concerning the use of government finances to achieve the macroeconomic goals. It has however, been variously defined by economists. According to Ionela and Diana (2010), fiscal policy is any decision to change the level, composition or timing of government expenditure or to vary the burden, structure or frequency of the tax payment. This definition presumes that the national economic goals are well articulated and specified. In other words, fiscal policy means that part of government policy concerning the raising of revenue through taxation and other means and deciding on the level and pattern of expenditure for the purpose of influencing economic activities. Dwivedi (2005) provides a more comprehensive definition of fiscal policy, at least, in the context of our present discussion. To him, 'fiscal policy is the government programmes of making discretionary changes in the pattern and level of its expenditure, taxation and borrowings in order to achieve intended economic growth, employment, income equality and stabilization of the economy. Globally, economies of the world are divided into three categories. These are: Advanced Economies, Economies in Transition and Developing Economies. However, for clarity and ease of analysis, we restrict the discussions in this paper to advanced and developing economies.

Fiscal policies have been widely used globally in different circumstances to 'stabilize' certain macroeconomic variables. In USA for instance, the investment tax credit (ITC) was introduced in 1962 and it provided businesses with strong incentive for equipment investment. It was adjusted frequently in response to changes in economic conditions of USA (Alan, 2005). In Turkey, Engin (2000) carried out a study which aimed at determining whether or not the economic stability is obtained by fiscal policy from 1985-1999. It was revealed that the fiscal policies regarding the internal and external borrowing and interest payments were unable to obtain economic stability; rather, they increased the rate of inflation within the period. Also, many OECD countries used fiscal policies at one time or the other to stabilize certain macroeconomic variables in their countries. Specifically, Allessandro and Claey (2010), in their study of the OECD countries applied an RBC model and the study revealed that temporary spending boosts in booms spur investment, and hence the need for external finance, and so generates very volatile cycles in investment and the current account.

In as much as fiscal policies are used globally to effect economic stability, a growing body of literature questioned whether government should actually counteract economic fluctuations, even if it were able to do so. The 'real business cycle' approach to economic fluctuations suggests that fluctuations in preferences and technology could account for observed business cycle fluctuations. That implies that some observed economic fluctuations are optimal, reflecting the responses of markets to taste and technology shocks. Therefore any attempt by the government to offset these fluctuations could be welfare reducing. In other words, if a temporary drop in production and a rise in unemployment were voluntary, given exogenous economic event, then, attempt to intervene by government would be inadvisable. Whatever is the nature of the debate, theoretical and empirical evidence indicate that fiscal policies are used and will continue to be used to stabilize global economy.

Our task in this paper is not to engage in the debate of whether the government (through fiscal policies) should intervene in the economy to stabilize the economy, or the arguments on the methodological issues. Our 
main concern is to identify (at least theoretically) the instruments of fiscal policies that are used to stabilize global economy and analyze their effectiveness as well as possible challenges. On that basis, we present the rest of the paper in six sections. Section two discusses fiscal policy for global economic stability; section three presents the role and effectiveness of fiscal policies. Section four presents the method and analysis of results, while the challenges of fiscal policies are discussed in section five, section six presents the concluding remarks.

\section{Fiscal Policy for Global Economic Stability}

Economic stability is one of the most important objectives of fiscal policy in both Developed Economies and the Less Developed Economies. Fiscal policy for global economic stability can take any of these three forms. (i) Automatic stabilization fiscal policy (ii) Discretionary fiscal policy changes (iii) Compensatory fiscal policy

(i) Automatic stabilization fiscal policy entails adopting a fiscal system with built-in flexibility of tax revenue and government spending. Built -in flexibility means automatic adjustment in government expenditure and tax revenue in response to a rise and fall in national income without government's deliberate action. As economic activity fluctuates, fiscal expenditures and taxes respond automatically in ways that stabilize the economy. For example, during an economic slowdown, government spending on unemployment benefits rises automatically as the unemployment rate rises. This increase in spending is automatic in that it does not require explicit actions by Congress or the President. Similarly, during the period of depression, taxes which are based on the percentage of national income automatically decline, thereby reducing the tax yields.

(ii) Discretionary measures include changes in taxation and government expenditure at the discretion of the government. Theoretically, such discretionary changes can guide the economy to the desired path and can be used to control economic depression and economic boom. Generally, it may take three forms.

(a) Changing tax rates with government expenditure constant. When taxes rates are increased while government expenditure remains constant, disposable income of households and business will reduce thereby curtailing aggregate demand. This approach is used to control high level of inflation.

(b) Changing government expenditure with tax rates constant. This is more useful in controlling deflationary tendencies. When government increases its expenditure on goods and services, keeping taxes constant, aggregate demand increases by the full amount of the increase in government expenditure. This is more suitable where depression is caused by decreasing aggregate demand.

(c) Variations in both expenditure and taxes simultaneously. This method, according to Jhingan (2010), is more effective in controlling inflationary and deflationary tendencies in the economy. To control inflation, taxes may be increased and government expenditure could be raised to fight depression.

(iii) Compensatory Fiscal policy is a deliberate budgetary action taken by the government to compensate for the deficiency in or excess of aggregate demand. The common budgetary policies that are used to stabilize the economy are deficit budget and surplus budget.

A deficit budget is used to stabilize the economy during the period of depression, especially, the depression caused by lack of effective demand. The compensatory measures may be in the form of tax reduction and enhanced government expenditure. These will lead to increase in aggregate demand which will result, first to increase price level leading to increase in producers' profits. The increase in profit creates an optimistic economic environment increasing the incentive to invest. This pushes up the levels of employment and output.

The policy of surplus budgeting is adopted and works effectively during the period of high level of inflation, particularly, when the cause of the inflation is excessive demand. The government may increase tax rate and reduce expenditure lower than revenue. Taxation reduces disposable income, thereby reducing aggregate demand at the rate of tax multiplier. On the expenditure side, a cut in government expenditure reduces aggregate demand at the rate of expenditure multiplier. These will reduce demand pressure and consequently, the inflation.

Expectations of future fiscal actions, and not just current expenditures and taxes, can also affect the economy. The distinction between current changes in spending or taxes and expected future changes is important because households and firms consider future economic conditions, as well as current conditions, in making their spending decisions. The impact of a change in fiscal policy today will depend on how it affects individuals' expectations about future government spending and taxes.

\section{The Role and Effectiveness of Fiscal Policies}

The role of fiscal policies in developed economies is to maintain full employment and stabilize growth. In contrast, in developing countries, fiscal policies are used to create an enabling environment for rapid economic growth. That can be done through:

1. Mobilization of resources: Developing economies are characterized by low levels of income and investment, which are linked in a vicious circle. This can be successfully broken by mobilizing resources for 
investment energetically.

2. Acceleration of economic growth: The government has not only to mobilize more resources for investment, but also to direct the resources to those channels where the yield is higher and the goods produced are socially acceptable.

3. Minimization of the inequalities of income and wealth: Fiscal tools can be used to bring about the redistribution of income in favor of the poor by spending revenue so raised on social welfare activities.

4. Increasing employment opportunities: Fiscal incentives, in the form of tax-rebates and concessions, can be used to promote the growth of those industries that have high employment-generation potentials.

5. Price stability: Fiscal tools can be employed to curtail inflationary and deflationary tendencies in the economy.

\section{Method and Analysis of Result}

The paper centers on the whole globe regarding the effectiveness of fiscal policy in stabilizing global economy. The economies of the world are generally divided into three. These are; Advanced Economies, Transition Economies and Developing Economies. For ease of analysis, we restrict the discussions on advanced and developing economies. The effectiveness of fiscal policies is analyzed based on the stability of annual GDP growth rate and some macroeconomic variables (Abachi, 2013). In that respect, the GDP and macroeconomic variables of selected advanced countries and selected LDCs are examined. The selected macroeconomic variables are inflation rate, exchange rate and unemployment rate. The data for this paper is obtained basically from World Bank. Tables and percentages as well as line graphs are used to analyze the issues raised.

The performance of annual growth rate and the selected macroeconomic variables are examined. The annual growth rates of selected advanced countries are presented in Table 1 below.

Table 1: Annual GDP Growth Rate (\%) of Selected Advanced Countries

\begin{tabular}{|l|l|l|l|l|l|l|l|l|l|l|}
\hline Country & 2003 & 2004 & 2005 & 2006 & 207 & 2008 & 2009 & 2010 & 2011 & 2012 \\
\hline UK & 3.8 & 2.9 & 2.8 & 2.6 & 3.6 & -1.1 & -4.0 & 1.8 & 1.0 & 0.3 \\
\hline USA & 2.6 & 3.5 & 3.1 & 2.7 & 1.9 & -0.4 & -3.1 & 2.4 & 1.8 & 2.2 \\
\hline France & .09 & 2.5 & 1.8 & 2.5 & 2.3 & -0.1 & -3.1 & 1.7 & 2.0 & 0.0 \\
\hline Germany & -0.3 & 1.2 & 0.7 & 3.7 & 3.3 & 1.1 & -5.1 & 4.2 & 3.0 & 0.7 \\
\hline
\end{tabular}

Source: htt://data.worlbank.org/indicator/NY.GDP.MI

As seen from Table 1, the annual growth rate of these countries ranges from $0 \%$ to $4 \%$ within the period covered. The rate has been relatively stable, except for the global economic crisis which affected almost all advanced economies in 2008 and 2009. The trends of the information are more clearly depicted in Figure 1 below.

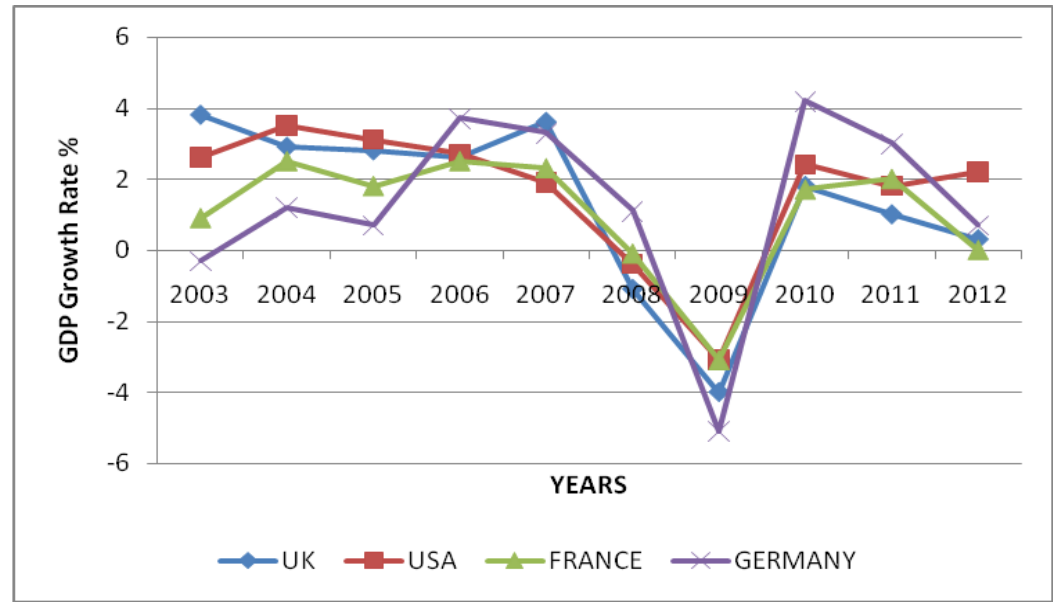

Figure 1: GDP Growth Rate (\%) of Selected Advanced Economies

The growth rate of the four advanced countries considered follows a similar pattern. From 2003 to 2007, the annual rate of growth was relatively stable between 0 to four percent. The global economic recession from 2008 and 2009 affected all the countries as their respective economies slumped in varying degrees and all picked up in 2010. 
Similarly, the GDP growth rate of selected Developing Economies is presented in Table 2 with the accompanied trends in Figure 2. As the table and the figure clearly show, the fluctuations in the growth rates of Kenya, Morocco and Nigeria were so high and do not follow any defined pattern to indicate stability. That of the other three countries, however, tries to pattern after the Advanced Economies. In Africa, it is the economy of South Africa that appears to step out to the sustained growth pattern.

Table 2: GDP Growth Rate (\%) of Selected Developing Economies

\begin{tabular}{|l|l|l|l|l|l|l|}
\hline Years/Countries & Kenya & Morocco & Nigeria & South Africa & Switzerland & Turkey \\
\hline 2003 & 2.9 & 6.3 & 10.3 & 2.9 & 0.0 & 5.3 \\
\hline 2004 & 5.1 & 4.8 & 10.6 & 4.6 & 2.4 & 9.4 \\
\hline 2005 & 5.9 & 3.0 & 5.4 & 5.3 & 2.7 & 8.4 \\
\hline 2006 & 6.3 & 7.8 & 6.2 & 5.6 & 3.8 & 6.9 \\
\hline 2007 & 7.0 & 2.7 & 6.4 & 5.5 & 3.8 & 4.7 \\
\hline 2008 & 1.1 & 5.6 & 6.0 & 3.6 & 2.2 & 0.7 \\
\hline 2009 & 2.7 & 4.8 & 7.0 & -1.5 & -1.9 & -4.4 \\
\hline 2010 & 5.8 & 3.6 & 8.0 & 3.1 & 3.0 & 9.2 \\
\hline 2011 & 4.4 & 5.0 & 7.4 & 3.5 & 1.9 & 8.8 \\
\hline 2012 & 4.6 & 2.7 & 5.6 & 2.5 & 1.0 & 6.9 \\
\hline
\end{tabular}

Source: htt://data.worlbank.org/indicator/NY.GDP.MI

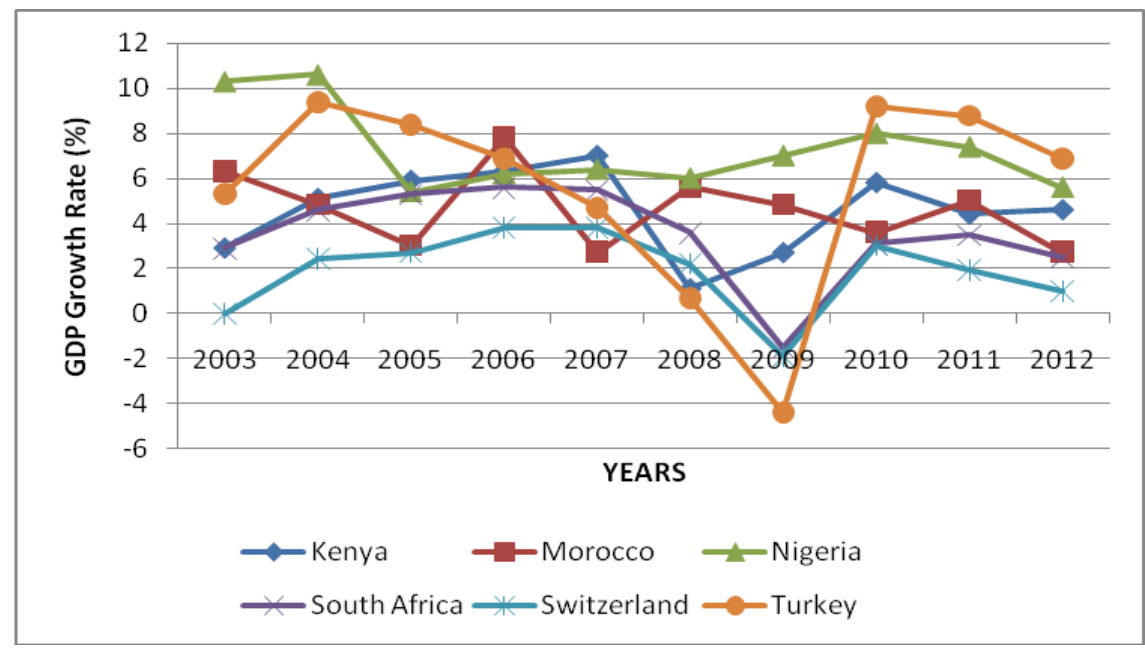

Figure 2: GDP Growth Rate of Developing Economies

Some macroeconomic variables are examined to determine the effectiveness of fiscal policies in stabilizing the global economy. These are inflation, exchange rate, and unemployment. The data on inflation and unemployment for selected Advanced and Developing countries is presented in Appendix 1, tables 1 and 2. Their respective figures are presented below in figures 3 and 5

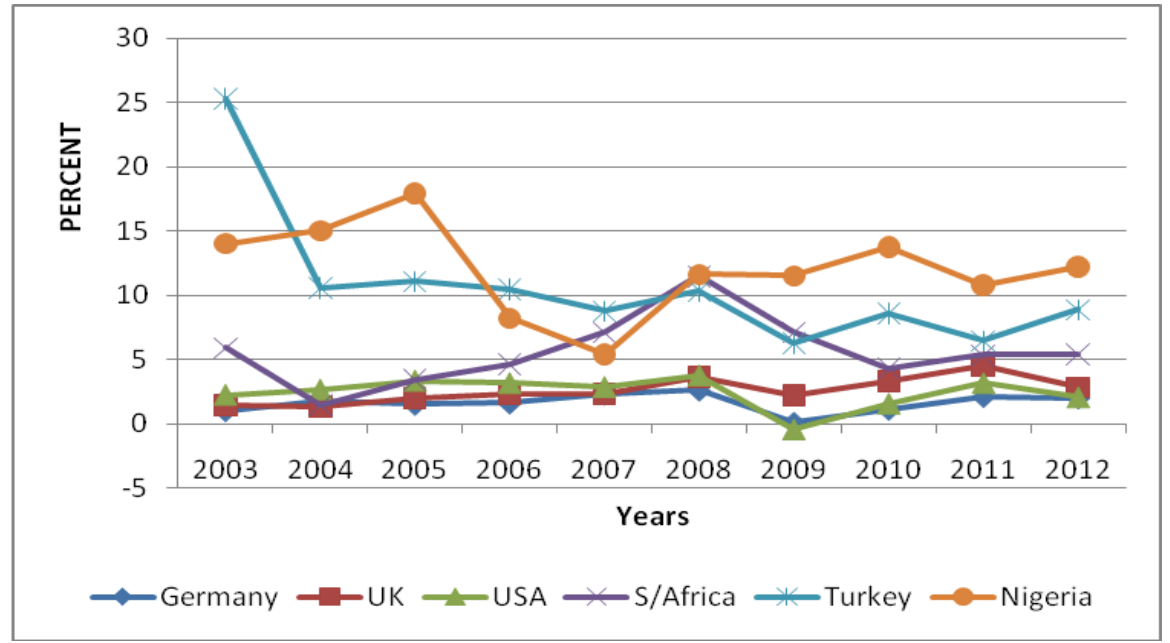

Figure 3: Inflation Rate for Selected Countries 
It is observed that inflation rates from Germany, UK and USA were relatively stable, approximately less than five percent from 2003 to 2012. That stabilized the economies and paved way for effective planning and meaningful projections. On the contrary, the inflation rates for the economies of the Developing Countries chosen ranged from 1 to 25 percent within the period. That does not show a defined pattern except in 2008 when the rate for all the three countries increased after which it took diverse patterns. That implies that fiscal policies in the Developing Economies have not been able to control inflation to enhance economic stability.

Given that the whole world is a global village and transactions of different sorts are undertaken among nations, the issue of exchange rate becomes very critical (Bonnet, 2007). And since almost all developing economies are import dependent, the value of the exchange rate determines the stability of these economies. Table 3 and Figure 4 indicate that the exchange rates of the advanced economies are stable. In UK, 1US\$ exchanges for less than $1 £$. In Canada her currency exchanges for approximately 1US\$ and that of Denmark, 1US\$ exchanges for an average of 5 of her currency. Compared with that of the selected Developing countries, the situation of the latter is disheartening. The Nigeria's case is worst as the exchange rate ranges from N118 to 1US\$ and N156 to 1US\$ within the period.

Table 3: Official Exchange Rate (Local Currency Units per US\$)

\begin{tabular}{|l|l|l|l|l|l|l|}
\hline Years/Countries & Canada & UK & Denmark & S/Africa & Algeria & Nigeria \\
\hline 2003 & 1.40 & 0.61 & 6.59 & 7.56 & 77.39 & 129.22 \\
\hline 2004 & 1.30 & 0.55 & 5.99 & 6.46 & 72.06 & 132.89 \\
\hline 2005 & 1.21 & 0.55 & 6.00 & 6.36 & 73.28 & 131.27 \\
\hline 2006 & 1.13 & 0.54 & 5.95 & 6.77 & 72.65 & 128.65 \\
\hline 2007 & 1.07 & 0.50 & 5.44 & 7.05 & 69.29 & 125.81 \\
\hline 2008 & 1.07 & 0.54 & 5.10 & 8.26 & 64.58 & 118.55 \\
\hline 2009 & 1.14 & 0.64 & 5.36 & 8.47 & 72.65 & 148.90 \\
\hline 2010 & 1.03 & 0.65 & 5.62 & 7.32 & 74.39 & 150.30 \\
\hline 2011 & 0.99 & 0.62 & 5.37 & 7.26 & 72.94 & 154.74 \\
\hline 2012 & 1.00 & 0.63 & 5.79 & 8.21 & 77.54 & 156.81 \\
\hline
\end{tabular}

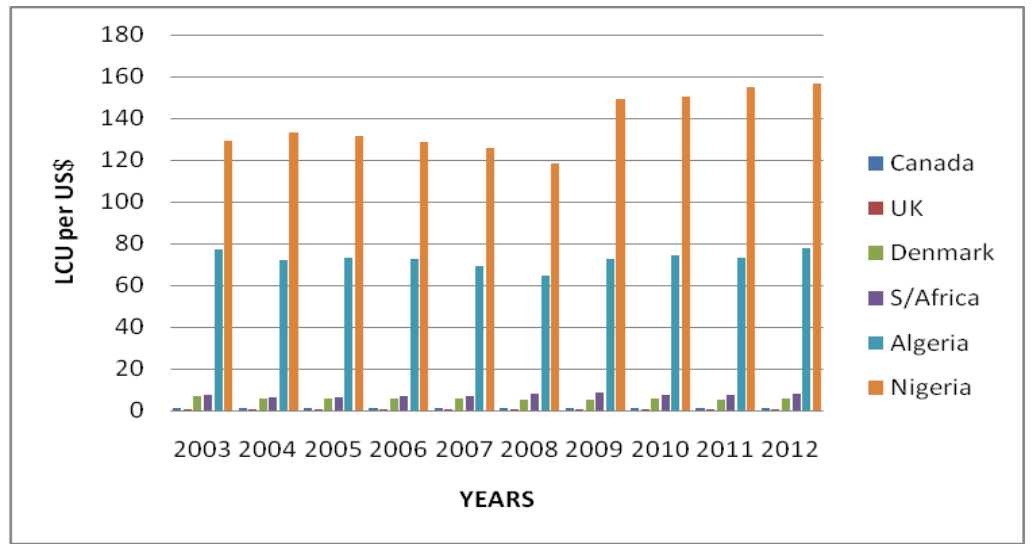

Figure 4: Official Exchange Rate

One of the major objectives of fiscal policies is to ensure full employment of resources. We therefore examine the rate of unemployment in selected countries as presented in Figure 5.

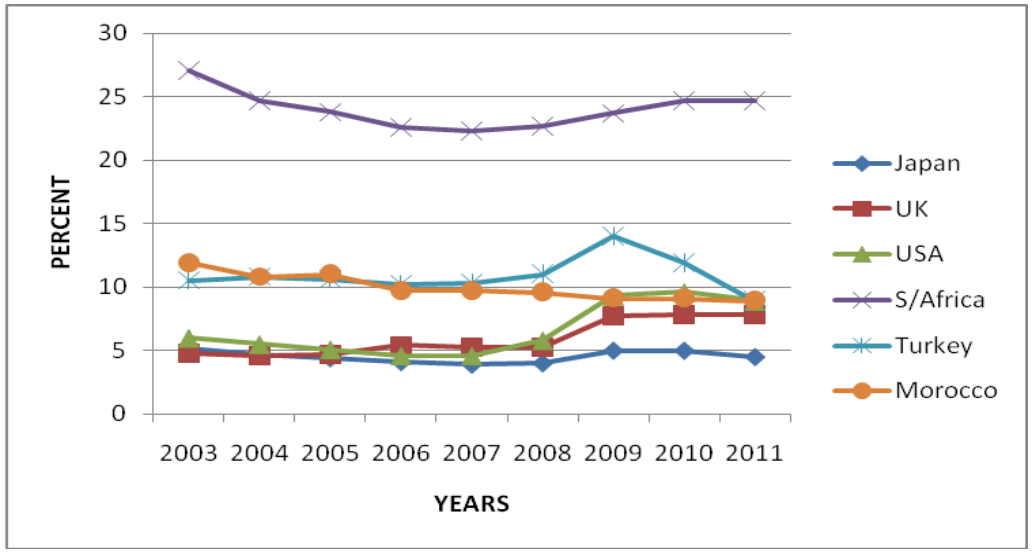


Figure 5: Unemployment Rates (Selected Countries)

The rate of unemployment of the Advanced Economies was relatively stable from 2003 to 2008 with slight increases during the global economic crisis. For the Developing Economies, that of Morocco and Turkey have been very high within the period but the one of South Africa was exceptionally high. Generally, the macroeconomic variables considered in this paper are more stable and perform better in advanced economies than in the developing economies. Therefore fiscal policies stabilize advanced economies while the developing economies are subjected to sustained instability.

\section{Challenges of Fiscal Policies for Global Economic Stability}

There are peculiar challenges to Developing Economies that make the fiscal policies to be ineffective. The following are some of them.

\section{High Level of Insecurity}

Given the September11 attack on the United States, the bombing in London and Bali, Tamil Tigers in Siri-Lanka, Kidnapping and the activities of Mafia in Mexico and Italy, Suicide bombings in Pakistan and Afghanistan, Piracy in Somalia, the ongoing uprising in the Middle East and North African countries, suicide bombings, Boko Haram insurgents in Nigeria, Political crisis and other forms of conflicts in many of the Developing Countries all suggest that security issues are a global phenomenon that posses a great challenge to global economic stability. It is generally observed that the issue of insecurity as a factor militating against the performance of fiscal policies to stabilize the global economy affects all economies but it effect on economic instability is more pronounced in developing economies (Eme and Onyishi, 2011).

The manifestation of insecurity has social and economic costs which affect the stability of economies in the following ways.

a) Social costs (loss of lives, social vices, etc)

b) Economic costs

$>$ Scares away investors (Both internal and external)

$>$ Increases the level of unemployment

$>$ Reduces internally generated revenue

$>$ Increases government expenditure

$>$ Reduces national output (GDP)

$>$ Depletes external reserves

$>$ Increases the rate of inflation

The severity of these costs is more in the Developing Economies than the Advanced Economies.

\section{High Level of Corruption}

Fiscal policies require efficient administrative machinery to be successful. No country in the world is corruption free but the level of corruption that destabilizes economic stability is more in the developing economies. Most developing economies have corrupt and inefficient administrations that fail to implement the requisite measures vis-à-vis the implementation of fiscal policy. Table 4 below clearly substantiates this claim. In the table, Denmark, Germany, UK, and USA are the chosen advanced economies while South Africa, Turkey, Ghana Egypt and Nigeria are the selected Developing Economies. The selection is based on the countries whose data on Corruption Perception Index is readily available.

Table 4: Corruption Perception Index for Advanced and Developing Economies

\begin{tabular}{|c|c|c|c|c|c|c|c|c|c|c|c|c|c|c|}
\hline Country & \multicolumn{2}{|c|}{2004} & \multicolumn{2}{|c|}{2005} & \multicolumn{2}{|c|}{2006} & \multicolumn{2}{|c|}{2007} & \multicolumn{2}{|c|}{2008} & \multicolumn{2}{|c|}{2009} & \multicolumn{2}{|c|}{2010} \\
\hline Denmark & 9.5 & 3 & 9.5 & 4 & 9.5 & 4 & 9.4 & 1 & 9.3 & 1 & 9.3 & 2 & 9.4 & NA \\
\hline UK & 8.6 & 11 & 8.6 & 11 & 8.6 & 11 & 8.4 & 12 & 7.7 & 16 & 7.7 & 17 & 7.6 & 20 \\
\hline USA & 7.5 & 17 & 7.6 & 17 & 7.3 & 20 & 7.2 & 20 & 7.3 & 18 & 7.5 & 19 & 7.1 & 22 \\
\hline S/Africa & 4.6 & 44 & 4.5 & 46 & 4.6 & 51 & 5.1 & 43 & 4.9 & 54 & 4.7 & 55 & 4.5 & 54 \\
\hline Ghana & 3.6 & 64 & 3.5 & 65 & 3.3 & 70 & 3.7 & 69 & 3.9 & 67 & 3.9 & 69 & 4.1 & 62 \\
\hline Egypt & 3.2 & 77 & 3.4 & 70 & 3.3 & 70 & 2.9 & 105 & 2.8 & 115 & 2.8 & 111 & 3.1 & 98 \\
\hline Nigeria & 1.6 & 144 & 1.8 & 152 & 2.2 & 142 & 2.2 & 147 & 2.7 & 121 & 2.5 & 130 & 2.4 & 134 \\
\hline $\begin{array}{l}\text { No. of } \\
\text { Countries }\end{array}$ & & 145 & & 158 & & 163 & & 183 & & 183 & & 180 & & 178 \\
\hline
\end{tabular}


Source: http://www.economywatch.com/economistat

$\mathrm{S}=$ Score; 10 means very clean, while 0 means highly corrupt

$\mathrm{R}=$ Rank. It indicates the country's position out of the number of Countries considered

It is clear that the CPI for advanced economies is very high, well above $70 \%$ for all the years considered while that of the developing economies is well below 50\%. It means there is very high level of corruption in the developing economies. Among the three developing countries chosen, Nigeria's CPI is the worst.

Corruption in Nigeria, among other things, weakens institutions, hampers investment and retards economic development. More importantly the resources that should be used for developmental purposes are being diverted to private or personal use. This accumulation of the nation's economic resources for personal benefits had variously contributed to the leakage of capital from Nigeria for illegal deposits abroad. In other words, it has a crowding out effect on the growth of the Nigerian economy.

Other challenges that appear to be peculiar to Developing Economies are;

\section{Rigid and Narrow Tax Structure}

The tax structure in Developing Economies is rigid and narrow; therefore the conditions necessary for the well integrated tax policies are absent. That is so because,

$>$ A sizeable proportion of the economy is non-monetized, thereby rendering fiscal measures of government ineffective and self defeating

$>$ Inadequate statistical information regarding income, expenditure, savings, investment, employment etc makes it difficult for the authority to formulate rational and effective fiscal policy.

$>$ Large scale tax evasion by people, who are not conscious of their roles in development, has an impact on fiscal policy

\section{Illiteracy}

Fiscal policy cannot succeed unless people understand its implications and cooperate with the government in its implementation. This is due to the fact that, in developing countries, majority of the people are illiterates.

\section{Concluding Remarks}

We conclude from this paper that fiscal policies have succeeded in stabilizing the economies of the advanced countries but have not performed well regarding developing economies. The identified challenges tend to work against the developing economies more than the advanced economies. It is argued that the advanced countries also passed through the stage the developing countries are undergoing at present. However, the high level of corruption and increased insecurity prevalent in these economies cast serious doubt whether the developing economies will ensure a sustained growth of their economies. It is therefore suggested that the issues of corruption and insecurity in Developing Economies be handled with all the seriousness it deserves to facilitate the effective performance of fiscal policies in these countries.

\section{References}

[1]. Abachi P. T (2013) “Growth Performance in Nigeria's Fiscal System” European Scientific Journal Vol. 9, No. 31

[2]. Alan J. Auerbach (2005) "Taxation and Capital Spending" Paper prepared for Academic Consultants Meeting of Board of the Federal Reserve System Eml.berkeley.edu/ auerbach/capital spending.pdf

[3]. Allessandro Maravalle and Claeys Peter (2010) "Fiscal Policy and Economic Growth; Does PIGS stand for Procyclicality in Government Spending?Research Institute of Applied Economics, Working paper 2010/15

[4]. Bennet Obi (2007) "Fiscal Policy and Poverty Alleviation: Some policy Options for Nigeria" African Economic Research Consortium, Naorobi

[5]. Dwivedi D. N (2005) Macroeconomics Theory and Policy Tata McGraw-Hill Publishing Company Ltd, Delhi

[6]. Eme Innocent and Anthony Onyishi (2011) "The Challenges of Insecurity in

[7]. Nigeria: A Thematic Exposition" Interdisciplinary Journal of Contemporary Research in Business Vol.3 No 8

[8]. Engin Oner (2000) "The Practices of Fiscal Policy for Economic Stability in Turkey (An Econometric Study:1985-1999) 224_lesij_es_xv_2_2008_art_25 (1).pdf

[9]. Ionela Popa and Diana Codreanu (2010) "Fiscal Policy and its Role in Ensuring Economic Stability" MPRA Paper No. $20820 \mathrm{http}: / / \mathrm{mpra}$.ub.uni-muenchen.de/20820/

[10]. Jhingan M.L (2010) Macroeconomic Theory $12^{\text {th }}$ Edition Vrinda Publishing (p) Ltd, Delhi

\section{Appendix 1}

Table 1: Global Inflation Rate

\begin{tabular}{|l|l|l|l|l|l|l|}
\hline Years/Countries & Germany & UK & USA & S/Africa & Turkey & Nigeria \\
\hline 2003 & 1.0 & 1.4 & 2.3 & 5.9 & 25.3 & 14.0 \\
\hline 2004 & 1.7 & 1.3 & 2.7 & 1.4 & 10.6 & 15.0 \\
\hline 2005 & 1.5 & 2.0 & 3.4 & 3.4 & 11.1 & 17.9 \\
\hline 2006 & 1.6 & 2.3 & 3.2 & 4.6 & 10.5 & 8.2 \\
\hline
\end{tabular}


Effectiveness Of Fiscal Policies In Stabalizing Global Economy

\begin{tabular}{|l|l|l|l|l|l|l|}
\hline 2007 & 2.3 & 2.3 & 2.9 & 7.1 & 8.8 & 5.4 \\
\hline 2008 & 2.6 & 3.6 & 3.8 & 11.5 & 10.4 & 11.6 \\
\hline 2009 & 0.13 & 2.2 & -0.4 & 7.1 & 6.3 & 11.5 \\
\hline 2010 & 1.1 & 3.3 & 1.6 & 4.3 & 8.6 & 13.7 \\
\hline 2011 & 2.1 & 4.5 & 3.2 & 5.3 & 6.5 & 10.8 \\
\hline 2012 & 2.0 & 2.8 & 2.1 & 5.4 & 8.9 & 12.2 \\
\hline
\end{tabular}

Source: World Bank

Table 2: Unemployment (\% of total labour force)

\begin{tabular}{|l|l|l|l|l|l|l|}
\hline Years/Countries & Japan & UK & USA & S/Africa & Turkey & Morocco \\
\hline 2003 & 5.2 & 4.8 & 6.0 & 27.1 & 10.5 & 11.9 \\
\hline 2004 & 4.7 & 4.6 & 5.5 & 24.7 & 10.8 & 10.8 \\
\hline 2005 & 4.4 & 4.7 & 5.1 & 23.8 & 10.6 & 11.0 \\
\hline 2006 & 4.1 & 5.4 & 4.6 & 22.6 & 10.2 & 9.7 \\
\hline 2007 & 3.9 & 5.3 & 4.6 & 22.3 & 10.3 & 9.7 \\
\hline 2008 & 4.0 & 5.3 & 5.8 & 22.7 & 11.0 & 9.6 \\
\hline 2009 & 5.0 & 7.7 & 9.3 & 23.7 & 14.0 & 9.1 \\
\hline 2010 & 5.0 & 7.8 & 9.6 & 24.7 & 11.9 & 9.1 \\
\hline 2011 & 4.5 & 7.8 & 8.9 & 24.7 & 8.9 & 8.9 \\
\hline
\end{tabular}

Source: World Bank 